\title{
Consensus Statement on Surgery Journal Authorship - 2006
}

In the majority of clinical and research studies submitted to surgery journals for possible publication, many individuals participate in the conception, execution, and documentation of each of those works. However, recognition of work in the form of authorship has varied widely. This consensus statement is being issued to clarify and define the criteria for surgical journal authorship.

The following guidelines should be used to identify individuals whose work qualifies them as authors as distinct from those who are contributors to the work under consideration. All persons designated as authors should qualify for authorship, and all those who qualify should be so credited.

\section{A. Authorship Criteria}

Individuals claiming authorship should meet all of the following 3 conditions:

1 Authors make substantial contributions to conception and design, and/or acquisition of data, and/or analysis and interpretation of data;

2 Authors participate in drafting the article or revising it critically for important intellectual content; and

3 Authors give final approval of the version to be submitted and any revised version to be published.

Each author should have participated sufficiently in the work to take public responsibility for appropriate portions of the content. Allowing one's name to appear as an author without having contributed significantly to the study or adding the name of an individual who has not contributed or who has not agreed to the work in its current form is considered a breach of appropriate authorship.

Acquisition of funding, collection of data, contributing cases, or general supervision of the research group, of itself, or just being the Chair of the department does not justify authorship if the above criteria are not fulfilled.

\section{B. Order of Authors}

The order of authorship on the byline should be a joint decision of the co-authors. Authors should be prepared to explain the order in which authors are listed.

\section{Multi-Center Studies}

When a large, multi-center group has conducted the work, the group should identify the individuals who accept direct responsibility for the manuscript. These individuals should fully meet the criteria for authorship defined above and editors will ask these individuals to complete journal-specific author and conflict of interest disclosure forms. When submitting a group-author manuscript, the corresponding author should clearly indicate the preferred citation and should clearly identify all individual authors as well as the group name.

\section{Contributors Listed in Acknowledgments}

All contributors who do not meet the criteria for authorship should be listed in an acknowledgments section. Examples of those who might be acknowledged include: individuals who allowed their clinical experience (i.e. cases) to be included, a person who provided purely technical help, writing assistance, or a department Chair who provided only general support. Financial and material support should also be acknowledged.

Groups of persons who have contributed materially to the paper but whose contributions do not justify authorship may be listed under a heading such as 'clinical investigators' or 'participating investigators,' and their function or contribution should be described - for example, 'served as scientific advisors,' 'critically reviewed the study proposal,' 'collected data,' or 'provided and cared for study patients.'

Because readers may infer their endorsement of the data and conclusions, all persons listed as contributors must give written permission to be acknowledged.

\section{E. In Conclusion}

This consensus statement is intended as a basic guide for authors. In the interest of promoting the highest ethics in surgical publishing and the surgical sciences, we ask that authors take these criteria into careful consideration when submitting a manuscript to a peer-reviewed surgical journal.

\section{KARGER}

Fax +41613061234 E-Mail karger@karger.ch www.karger.com
(C) 2006 S. Karger AG, Basel

0253-4886/06/0233-0137\$23.50/0

Accessible online at:

www.karger.com/dsu 


\section{This statement is being simultaneously published in the respective journals of the}

members of the Surgical Journal Editors Group, as follows:

American Journal of Surgery: Kirby I. Bland, MD

The American Surgeon: Talmadge A. Bowden, Jr., MD

Annals of Surgery: Layton F. Rikkers, MD

Annals of Surgical Oncology: Charles M. Balch, MD

Annals of Thoracic Surgery: L. Henry Edmunds, Jr., MD

Archives of Surgery: Julie Freischlag, MD

British Journal of Surgery: John Murie, MD

Canadian Journal of Surgery: Garth L. Warnock, MD, James P. Waddell, MD

Current Surgery: John A. Weigelt, MD

Digestive Surgery: Markus Büchler, MD, John Neoptolemos, MD

Diseases of the Colon and Rectum: Victor Fazio, MD

Journal of the American College of Surgeons: Timothy J. Eberlein, MD

Journal of Burn Care and Research: Richard Gamelli, MD

Journal of Gastrointestinal Surgery: John Cameron, MD, Keith Kelly, MD

Journal of the Japan Medical Surgical Association: Yasuo Idezuki, MD

Journal of Laparoendoscopic \& Advanced Surgical Techniques: Mark Talamini, MD

Journal of Parenteral and Enteral Nutrition: Charles Van Way, III, MD

Journal of Pediatric Surgery: Jay Grosfeld, MD

Pediatric Surgery International: Arnold G. Coran, MD, Prem Puri, MD

Journal of Pelvic Medicine and Surgery: Robert D. Madoff, MD

Journal of Plastic \& Reconstructive Surgery: Rod J. Rohrich, MD

Journal of Surgical Research: David McFadden, MD, Wiley W. Souba, MD

Journal of Trauma: Basil A. Pruitt, Jr., MD

Journal of Thoracic \& Cardiovascular Surgery: Andrew S. Wechsler, MD

Journal of Vascular Surgery: Jack L. Cronenwett, MD, James M. Seeger, MD

Surgery: Andrew L. Warshaw, MD, Michael Sarr, MD

Surgical Endoscopy: Bruce V. MacFadyen, Jr., MD, Alfred Cuschieri, MD

Surgical Laparoscopy, Endoscopy \& Percutaneous Techniques: Maurice E. Arregui, MD, Carol Scott-Conner, MD

World Journal of Surgery: John G. Hunter, MD

Zentralblatt für Chirurgie: Hans Lippert, MD

This Consensus statement was adapted from the International Committee of Medical Journal Editors Uniform Requirements for Manuscripts Submitted to Biomedical Journals.

For more information: http://www.icmje.org/index.html

Markus W. Büchler

John P. Neoptolemos

Editors 